\title{
Efek Antidiabetik Ekstrak Daun Gendola (Basella rubra L.) Terhadap Kadar Gula Darah Tikus Putih
}

\section{Antidiabetic Effects of Gendola (Basella rubra L.) Leaf Extract on Blood Glucose Levels in Albino Rats}

\author{
Angelica Diana Vita ${ }^{1 *}$, Nurmawati Fatimah ${ }^{2}$, Sri Murtiwi ${ }^{3}$ \\ ${ }^{1}$ Medical Science Program, ${ }^{2}$ Department of Pharmacology, ${ }^{3}$ Department of Internal Medicine, \\ Faculty of Medicine, Universitas Airlangga, \\ UNAIR A-Campus, Tambaksari, Surabaya, East Java, Indonesia 60132 \\ Telp. (031)5034509 \\ *Corresponding author: angelica.diana@ rocketmail.com
}

\begin{abstract}
Abstrak
Penelitian bertujuan untuk menguji efek antidiabetik ekstrak daun gondola (Basella rubra L.) pada kadar gula darah tikus putih (Rattus norvegicus) yang diinduksi Alloxan. Penelitian ini merupakan penelitian eksperimen dengan menggunakan 35 ekor tikus putih. Tikus tersebut dibagi menjadi lima kelompok perlakuan, yakni: P1; P2; P3; kontrol negatif (K-); dan kontrol positif $(\mathrm{K}+)$. Masing-masing kelompok diinduksi menggunakan Alloxan untuk meningkatakan kadar gula darah. Kelompok P1; P2; P3 diberi ekstrak daun gendola dengan dosis 200; 300; $400 \mathrm{mg} / \mathrm{kgBB} / \mathrm{hari}$. Kelompok K+ diberi obat glimepirid $0.1 \mathrm{mg} / \mathrm{kgBB} / \mathrm{hari}$. Kelompok P1 mengalami penurunan kadar gula darah yang tidak signifikan sebesar $30.14 \mathrm{mg} / \mathrm{dL}$ (pvalue=0.128); kelompok P2 mengalami penurunan kadar gula darah tidak signifikan sebesar $25.80 \mathrm{mg} / \mathrm{dL}$ (pvalue=0.159); kelompok P3 mengalami penurunan kadar gula darah yang signifikan sebesar $42.80 \mathrm{mg} / \mathrm{dL}$ (pvalue $=0.043$ ). Kelompok kontrol negatif mengalami peningkatan kadar gula darah sebesar $116.00 \mathrm{mg} / \mathrm{dL}(\mathrm{p}-$ value=0.084). Kelompok kontrol positif mengalami penurunan kadar gula darah yang signifikan sebesar 21.60 $\mathrm{mg} / \mathrm{dL}$ (p-value=0.011). Ekstrak daun gendola $400 \mathrm{mg} / \mathrm{kgBB} / \mathrm{hari}$ dapat menurunkan kadar gula darah tikus dengan perbedaan tidak signifikan apabila dibandingkan dengan obat antidiabetes glimepirid $0.1 \mathrm{mg} / \mathrm{kgBB} / \mathrm{hari}$.
\end{abstract}

Kata kunci: diabetes melitus, gendola, tikus putih, Basella rubra L., Alloxan

\section{Abstract}

This study aimed to measure the effect of ethanol extract of gendola leaves (Basella rubra L.) on decreasing blood glucose levels in albino rats (Rattus norvegicus) induced by Alloxan. This study was an experimental study using 35 albino rats. The rats were divided into five groups, i.e., treatment group P1; P2; P3; negative control (K-); and positive control $(K+)$. Each group was induced with Alloxan to increase blood glucose levels. P1; P2; P3 groups were given 200; 300; $400 \mathrm{mg} / \mathrm{kgBW} /$ day dosage of gendola leaf extract dose, while the $K+$ group was given glimepirid $0.1 \mathrm{~kg} / \mathrm{kgBW} /$ day. Group P1 had an insignificant decrease in blood glucose levels by $30.14 \mathrm{mg} / \mathrm{dL}$ (p-value=0.128); P2 group experienced an insignificant decrease in blood glucose levels by $25.80 \mathrm{mg} / \mathrm{dL}$ ( $p$-value=0.159); the P3 group had a significant decrease in blood glucose levels by $42.80 \mathrm{mg} / \mathrm{dL}$ ( $p$-value=0.043). The negative control group had an increase in blood glucose level by 116.00 $\mathrm{mg} / \mathrm{dL}$ ( -value=0.084). The positive control group had a significant decrease in blood glucose levels by 21.60 $\mathrm{mg} / \mathrm{dL}$ (p-value=0.011). Gendola leaf extract with the dosage of $400 \mathrm{mg} / \mathrm{kgBW} /$ day can reduce blood glucose levels in albino rats with insignificant difference when compared with antidiabetic drug such as glimepirid 0.1 $m g / k g B W / d a y$.

Key words: diabetes mellitus, gendola, albino rats, Basella rubra L., Alloxan

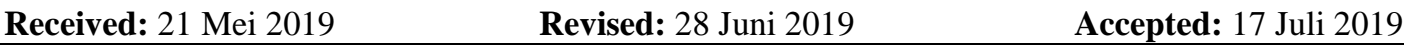

\section{PENDAHULUAN}

Tanaman gendola atau binahong merah (Basella rubra L.) dikenal sebagai tanaman toga atau tanaman obat yang dapat digunakan untuk merawat luka sebagai antibakteri. Daun dan buah gendola banyak dimanfaatkan sebagai bahan obat tradisional untuk radang usus buntu, 
disentri, influenza, radang kandung kemih, campak dan cacar air, luka memar terpukul, asam urat, dan ambeien, menyembuhkan luka dalam dan luar setelah operasi, mengatasi pembengkakan dan pembekuan darah, memulihkan kondisi lemah setelah sakit, serta mencegah stroke. Tanaman gendola merupakan tanaman yang dapat dijadikan bahan obat alami karena mengandung senyawa aktif dari golongan flavonoid, saponin, dan polifenol (Sitorus dkk., 2011).

Diabetes melitus merupakan suatu penyakit yang ditandai dengan adanya sindroma hiperglikemia yang mengakibatkan gangguan pada proses metabolisme karbohidrat, lemak, maupun protein. Penyakit ini dapat disebabkan oleh genetik seseorang dan juga dapat dipicu oleh lifestyle seseorang (Suryani dkk., 2015).

Penyakit diabetes melitus dapat disebabkan oleh sel pankreas yang tidak dapat memproduksi insulin maupun disebabkan oleh ketidakefektifan kerja insulin karena adanya resistensi insulin pada organ tubuh manusia. Hal tersebut mengakibatkan diabetes membutuhkan pengobatan yang tepat sesuai dengan mekanisme yang mendasarinya. Apabila diabetes disebabkan karena penurunan fungsi sel pankreas, maka terapi yang dapat diberikan berupa insulin, sulfonilurea, meglitinid, Glucagon-like Peptide-1 (GLP-1) agonis dan Dipeptidyl Peptidase 4 (DPP-4) inhibitor. Apabila penyakit diabetes tersebut disebabkan oleh resistensi organ, maka terapi dapat disesuaikan dengan titik organ tersebut, misalnya penggunaan metformin untuk membatasi glukoneogenesis pada liver (Rudijanto et al., 2015).

Terapi-terapi tersebut memiliki beberapa efek samping yang kurang menguntungkan bagi penggunanya, seperti efek hipoglikemik. Penggunaan metformin pada penderita diabetes juga dapat menimbulkan efek samping berupa hipoglikemik serta gangguan pada gastrointestinal. Obat golongan sulfonilurea seperti glimepirid juga menimbulkan efek samping serupa dengan penggunaan metformin, yaitu mual dan muntah. Beberapa terapi antidiabetes juga membutuhkan biaya mahal serta memiliki efek samping yang bermacammacam (Katzung et al., 2012).

Berdasarkan data WHO 2011, saat ini telah tercatat lebih dari 100.000 industri terapi herbal di dunia. Penerapan terapi herbal sendiri sudah sering dilakukan di masyarakat Indonesia sebagai suatu alternatif untuk mengobati berbagai macam penyakit, termasuk diabetes melitus. Hal tersebut dipengaruhi dari segi motivasi diri, segi sosial ekonomi, dan juga segi pendidikan dari masyarakat. Masyarakat Indonesia meyakini bahwa terapi herbal mampu memberikan terapi dengan efek samping yang lebih sedikit dengan harga yang lebih terjangkau (Leonita dan Muliani, 2015).

Penelitian ini dilakukan dengan tujuan untuk mengamati adanya pengaruh dari ekstrak etanol daun gendola terhadap kadar gula darah tikus putih yang diinduksi Alloxan.

\section{METODE PENELITIAN}

\section{Etik Hewan Coba}

Penelitian dilaksanakan di Laboratorium Farmakologi Fakultas Kedokteran Universitas Airlangga dengan metode eksperimen. Penelitian ini dilaksanakan dengan dasar sertifikat etik (ethical clearance) Komite Etik Penelitian Kesehatan Fakultas Kedokteran Universitas Airlangga Surabaya dengan nomor seritifikat 274/EC/KEPK/FKUA/2018.

\section{Persiapan Ekstrak Daun Gendola}

Pengambilan data penelitian dilakukan dari bulan November 2018 hingga Desember 2018. Peralatan yang digunakan terdiri atas timbangan analitik, alat injeksi Terumo $10 \mathrm{cc} / \mathrm{ml}$, dan juga glukometer Autocheck 3 in 1. Bahan yang digunakan terdiri atas Alloxan dengan dosis 150 $\mathrm{mg} / \mathrm{kgBB}$, glimepirid $0.1 \mathrm{mg} / \mathrm{kgBB} / \mathrm{hari}$, dan ekstrak etanol daun gendola dengan dosis masing-masing $200 \mathrm{mg} / \mathrm{kgBB} / \mathrm{hari}, \quad 300$ $\mathrm{mg} / \mathrm{kgBB} / \mathrm{hari}$, dan $400 \mathrm{mg} / \mathrm{kgBB} / \mathrm{hari}$.

\section{Adaptasi Hewan Coba}

Tikus putih yang digunakan pada penelitian ini merupakan tikus jantan, usia rata-rata 8 minggu, memiliki berat badan dengan rentang 
200-250gram, dan dilakukan aklimatisasi selama 1 minggu. Jumlah sampel penelitian didapatkan dari rumus Federer sejumlah 5 dan untuk cadangan disediakan $10 \%$, sehingga total tikus putih yang tersedia paling tidak 30 buah tikus. Pada penelitian ini, jumlah sampel yang disediakan 35 ekor tikus putih.

\section{Perlakuan}

Penelitian ini membagi tikus putih menjadi 5 kelompok, yakni: (P1) tikus putih diabetes yang diberi ekstrak daun gendola $200 \mathrm{mg} / \mathrm{kgBB} / \mathrm{hari}$; (P2) tikus putih diabetes yang diberi ekstrak daun gendola $300 \mathrm{mg} / \mathrm{kgBB} / \mathrm{hari}$; (P3) tikus putih diabetes yang diberi ekstrak daun gendola $400 \mathrm{mg} / \mathrm{kgBB} / \mathrm{hari}$; (K-) tikus putih diabetes yang tidak diberikan perlakuan; $(\mathrm{K}+)$ tikus putih diabetes yang diberi obat glimepirid 0.1 $\mathrm{mg} / \mathrm{kgBB} /$ hari. Pemberian Alloxan untuk semua kelompok tikus diberikan secara injeksi intraperitoneal Alloxan untuk meningkatkan kadar gula darah.

\section{Pengujian Gula Darah}

Pemeriksaan kadar gula darah dilakukan dua kali, yaitu setelah disuntik Alloxan dan setelah diberikan perlakuan, dengan memeriksa kadar gula darah perifer yang didapatkan dari memotong ujung ekor tikus putih tersebut.

\section{Analisis Data}

Data dianalisa menggunakan SPSS versi 16 meliputi uji normalitas Shapiro-Wilk, kemudian dilakukan uji Wilcoxon Signed Rank dan Paired T-Test untuk membandingkan data sebelum dan sesudah perlakuan. Kemudian dilakukan uji Mann-Whitney untuk membandingkan hasil antar kelompok. Data juga dianalisa menggunakan uji korelasi Pearson untuk menentukan hubungan antara berat badan dengan peningkatan kadar gula darah tikus putih setelah diberi Alloxan.

\section{HASIL DAN PEMBAHASAN}

\section{Data Dasar Tikus Putih}

Pada penelitian ini ditemukan persebaran data yang homogen pada tikus putih sebelum pemberian Alloxan. Tiga puluh satu tikus putih memiliki jenis kelamin yang sama, usia yang sama, persebaran data berat badan yang normal, dan juga persebaran data gula darah puasa yang normal. Setelah diinjeksi dengan Alloxan, tikus putih memiliki kadar gula darah puasa dengan persebaran data yang tidak normal (Tabel 1). Hal tersebut menandakan adanya respon tikus putih yang berbeda-beda terhadap pemberian Alloxan. Hal tersebut dapat disebabkan oleh faktor Alloxan maupun faktor dari hewan coba.

\section{Hubungan Berat Badan dengan Kadar Gula Darah}

Berdasarkan data dasar tikus putih pada Tabel 1 dan statistik Pearson yang tertera pada Tabel 2, korelasi antara berat badan tikus dengan peningkatan kadar gula darah tikus putih tidak signifikan. Kelompok P1, P3, dan $\mathrm{K}+$ menyatakan adanya korelasi positif antara berat badan tikus putih dengan kadar gula darah, yang berarti semakin tinggi berat badan tikus tersebut maka akan semakin tinggi pula kadar gula darahnya. Kelompok P2 dan K- memiliki korelasi negatif antara berat badan tikus putih dengan kadar gula darah, yang berarti semakin tinggi berat badan tikus tersebut maka kadar gula darahnya akan justru semakin rendah. Hal tersebut menunjukkan bahwa adanya hubungan yang tidak konsisten maka korelasi tersebut bernilai tidak signifikan. Hal tersebut dapat dikarenakan oleh karena kesalahan pemberian dosis Alloxan yang didasarkan oleh berat ratarata seluruh tikus dalam satu kelompok dan tidak menggunakan berat badan dari masing-masing tikus, sehingga Alloxan tidak dapat bekerja dengan efektif. Untuk masing-masing kelompok, penulis memperhitungkan $150 \mathrm{mg} / \mathrm{kgBB}$ Alloxan untuk 31 tikus putih dengan menggunakan berat badan $200 \mathrm{mg}$ dalam perhitungan banyak Alloxan yang akan diinjeksikan.

\section{Pengaruh Ekstrak Daun Gendola terhadap Kadar Gula Darah}

Pada tabel 1, didapatkan perubahan kadar gula darah sebesar $42.80 \mathrm{mg} / \mathrm{dL}$ pada penggunaan ekstrak daun gendola dengan dosis $400 \mathrm{mg} / \mathrm{kgBB} /$ hari. Penggunaan dua dosis lain 
Tabel 1. Kadar gula darah puasa (GDP) (mg/dl) tikus putih selama perlakuan

\begin{tabular}{cccc}
\hline \multirow{2}{*}{ Perlakuan } & \multicolumn{3}{c}{ Mean \pm SD } \\
\cline { 2 - 4 } & GDP pre Alloxan & GDP post Alloxan & Penurunan GDP ekstrak gendola \\
\hline K- & $85.50^{\mathrm{a}} \pm 7.89$ & $157.33^{\mathrm{b}} \pm 79.47$ & $-116.00^{\mathrm{NS}^{\mathrm{a}} \pm 132.28}$ \\
$\mathrm{~K}+$ & $92.00^{\mathrm{a}} \pm 10.05$ & $167.00^{\mathrm{b}} \pm 121.54$ & $21.60^{\mathrm{a}} \pm 10.74$ \\
P1 & $107.43^{\mathrm{b}} \pm 19.69$ & $259.14^{\mathrm{d}} \pm 223.37$ & $30.14^{\mathrm{a}} \pm 46.47$ \\
P2 & $115.71^{\mathrm{b}} \pm 10.06$ & $189.00^{\mathrm{c}} \pm 110.00$ & $25.80^{\mathrm{a}} \pm 33.43$ \\
P3 & $95.00^{\mathrm{a}} \pm 6.45$ & $313.60^{\mathrm{d}} \pm 204.54$ & $42.80^{\mathrm{b}} \pm 33.60$ \\
\hline
\end{tabular}

Superskrip berbeda pada kolom yang sama menunjukkan perbedaan signifikan $(\mathrm{p}<0.05)$

Tabel 2. Tabel hubungan berat badan dan kadar gula darah tikus putih

\begin{tabular}{cccc}
\hline Kelompok & N & p-value & Pearson Correlation \\
\hline K- & 6 & 0.748 & -.170 \\
K+ & 5 & 0.791 & 0.165 \\
P1 & 7 & 0.892 & 0.063 \\
P2 & 5 & 0.493 & -.410 \\
P3 & 5 & 0.990 & 0.008
\end{tabular}

yang lebih rendah, yaitu $200 \mathrm{mg} / \mathrm{kgBB} / \mathrm{hari}$ dan $300 \mathrm{mg} / \mathrm{kgBB} / \mathrm{hari}$ juga menimbulkan penurunan pada kadar gula darah, yaitu $30.14 \mathrm{mg} / \mathrm{dL}$ dan $25.80 \mathrm{mg} / \mathrm{dL}$. Selain menggunakan ekstrak daun gendola, penelitian ini juga menggunakan obat glimepirid pada kelompok kontrol positif, dan hasilnya memang menunjukkan penurunan kadar gula darah sebesar $21.60 \mathrm{mg} / \mathrm{dL}$. Penurunan kadar gula darah pada kelompok tikus yang diberi ekstrak daun gendola $400 \mathrm{mg} / \mathrm{kgBB} / \mathrm{hari}$ dibandingkan dengan yang diberi obat glimepirid memiliki perbedaan yang tidak signifikan.

Kadar gula darah tikus sebelum dan sesudah diberi ekstrak etanol daun gendola 200 $\mathrm{mg} / \mathrm{kgBB} / \mathrm{hari}$ dan $300 \mathrm{mg} / \mathrm{kgBB} / \mathrm{hari}$ mengalami penurunan yang tidak signifikan $(\mathrm{p}<0.05)$, sedangkan untuk tikus yang diberi ekstrak daun gendola $400 \mathrm{mg} / \mathrm{kgBB} / \mathrm{hari}$ dan dengan pengobatan glimepirid terdapat perubahan yang berarti $(\mathrm{p}>0.05)$.

Berdasarkan Tabel 1, kelompok P3 dan $\mathrm{K}+$ mengalami penurunan kadar gula darah yang signifikan antara sebelum dan sesudah pemberian ekstrak etanol daun gendola 400 $\mathrm{mg} / \mathrm{kgBB} /$ hari dan juga dengan pemberian obat glimepirid. Hasil nilai $\mathrm{p}$ adalah 0.085 yang berarti tidak terdapat perbedaan signifikan antara pemberian ekstrak daun gendola 400 $\mathrm{mg} / \mathrm{kgBB} /$ hari dengan pemberian obat glimepirid $0.1 \mathrm{mg} / \mathrm{kgBB} / \mathrm{hari}$.
Dari segi data, dapat diketahui bahwa standar deviasi dari kelompok P1 dan P2 lebih besar apabila dibandingkan dengan standar deviasi pada kelompok K+. Standar deviasi untuk P1 dan P2 lebih besar dibandingkan dengan rata-rata gula darah pre dan post, yang menandakan bahwa rata-rata dari gula darah kelompok tersebut tidak dapat mewakili keseluruhan data. Adanya standar deviasi ini dapat disebabkan oleh penggunaan Alloxan, yang memiliki sifat instabilitas, sehingga kadar gula darah dapat mengalami peningkatan atau penurunan selama tikus diberikan terapi.

Penyebab lainnya yang dapat menyebabkan hal tersebut adalah jumlah tikus putih dari masing-masing kelompok perlakuan lebih banyak dibandingkan dengan jumlah tikus pada kelompok kontrol positif, sehingga variasi data yang bermacam-macam akan mempengaruhi standar deviasi yang ada, sehingga akan menimbulkan hasil perubahan akhir yang tidak signfikan.

\section{Pengaruh Alloxan terhadap Kadar Gula Darah}

Penelitian ini memanfaatkan Alloxan untuk menginduksi peningkatan kadar gula darah tikus. Akan tetapi, kadar gula darah puasa awal yang dihasilkan memiliki rentang deviasi yang luas, artinya terdapat kadar gula darah yang 
memenuhi kriteria inklusi (yaitu $135 \mathrm{mg} / \mathrm{dL}$ ), namun ada juga tikus dengan kadar gula darah yang rendah. Hal ini disebabkan sifat instabilitas dan auto-reversibility Alloxan.

Instabilitas dan auto-reversibility dari Alloxan yang dimaksud adalah adanya respon kadar gula darah yang multifasik, yaitu adanya peningkatan dan penurunan kadar gula darah yang inkonsisten, sehingga Alloxan merupakan substansi yang kurang stabil apabila digunakan untuk pengamatan sebuah penelitian. Bahkan ketika stabilitas dari gula darah tersebut tercapai, kadar tersebut tidak akan bertahan hingga satu bulan, yang membuat Alloxan kurang baik untuk dijadikan bahan pengamatan eksperimen (Lenzen, 2008).

Lenzen (2008) mengatakan bahwa kadar gula darah tikus memiliki respon yang multifasik terhadap pemberian Alloxan. Beberapa menit pertama setelah injeksi, tikus akan mengalami hipoglikemia yang bertahan maksimal 30 menit, kemudian akan mengalami hiperglikemia 1 jam setlah injeksi, kemudian diikuti kembali oleh fase hipoglikemik yang bertahan beberapa jam (umumnya 3 jam), kemudian kadar gula darah tikus akan mengalami hiperglikemia permanen dalam kurun waktu 24-48 jam setelah injeksi. Umumnya pemberian glukosa 5-10\% digunakan untuk mengurangi mortalitas pada tikus yang mengalami hipoglikemia, akan tetapi efek protektif yang diberikan tidak terlalu besar.

Alloxan menyebabkan diabetes melalui mekanisme partial degradation dari sel beta pankreas, memanfaatkan fasilitasi dari Glucose Transporter 2 (GLUT2) untuk masuk ke sel dan juga memiliki mekanisme induksi Reactive Oxygen Species (ROS) yang akan menyebabkan nekrosis pada sel. Selain Alloxan, glukosa juga memanfaatkan GLUT2 untuk measuk ke dalam sel. Keadaan darah yang tinggi akan glukosa akan menyebabkan Alloxan bersaing dengan glukosa untuk berikatan dengan GLUT2, dan juga menyebabkan uptake-nya yang tidak maksimal. Hal tersebut menyebabkan efek diabetogenik yang tidak sempurna, sehingga tikus sebaiknya tidak diberi makan kurang lebih 12 jam sebelum penyuntikkan Alloxan. Akan tetapi, bertentangan dengan poin sebelumnya, setelah injeksi Alloxan, tikus akan diberi larutan glukosa 5-10\% untuk mengurangi mortalitas tikus yang diakibatkan oleh hipoglikemia. Hal ini menyebabkan terdapat beberapa tikus yang memiliki kadar gula darah tinggi, ada pula yang normal (Lenzen, 2008).

Alloxan merupakan substansi yang tidak stabil dan memiliki half-life selama 1,5 menit dan mudah sekali disintegrasi pada larutan aqueous, sehingga setiap penelitian harus memanfaatkan Alloxan yang selalu baru. Apabila sebuah penelitian terdiri dari banyak hewan coba, kelompok hewan coba yang diinjeksi terakhir tidak mendapatkan efek diabetogenik seperti pada kelompok hewan coba yang diinjeksi pertama kali akibat disintegrasi Alloxan (Lenzen, 2008).

Half-life Alloxan yang singkat menyebabkan administrasi substansi tersebut pun harus secepat mungkin. Rute yang dianjurkan adalah melalui intravena (IV), namun injeksi intravena memiliki risiko mortalitas yang tinggi dan susah untuk dilakukan pada hewan coba, sehingga injeksi intraperitoneal lebih sering diterapkan dalam percobaan eksperimen. Salah satu cara untuk mengatasi hal tersebut adalah dengan segera menyuntikkan substansi tersebut setalah siap dalam bentuk larutan (Lenzen, 2008).

\section{Pengaruh Glimepirid terhadap Kadar Gula Darah}

Pada kelompok tikus putih yang diberi obat glimepirid rata-rata penurunan kadar gula darah kelompok tikus yang diberi glimepirid sebesar $21.60 \mathrm{mg} / \mathrm{dL}$ dengan persebaran data yang normal, artinya standar deviasi tidak terlalu besar antar tikus dalam kelompok tersebut. Pada Tabel 1, didapatkan bahwa perbedaan antara gula darah sebelum dan setelah pemberian glimepiride yang signifikan.

Menurut Mwafy dan Yassin (2011), glimepirid sebesar $0.1 \mathrm{mg} / \mathrm{kgBB} / \mathrm{hari}$ yang diberikan pada tikus dapat membantu menurunkan kadar gula darah tikus.

\section{Faktor-Faktor yang Mempengaruhi}

Faktor hewan coba adalah faktor genetik dan faktor stres dari tikus. Alloxan memiliki 
kespesifikan terhadap sel beta pankreas, namun hal tersebut juga dipengaruhi oleh genetik masing-masing tikus berkaitan dengan ekspresi reseptor pada sel pankreas, sehingga respon masing-masing tikus terhadap pemberian Alloxan berbeda-beda (Saputra et al., 2018).

Selain faktor genetik juga terdapat faktor stres tikus, yang menyebabkan produksi hormon epinefrin dan kortisol meningkat. Peningkatan kedua hormon tersebut berkaitan erat dengan peningkatan gula darah pada tikus. Hal ini yang menyebabkan standar deviasi kadar gula darah sebelum perlakuan sangat besar (Saputra et al., 2018).

\section{KESIMPULAN}

Ekstrak etanol daun gendola (Basella rubra L.) dosis $400 \mathrm{mg} / \mathrm{kgBB} / \mathrm{hari}$ signifikan menurunkan kadar gula darah pada tikus putih yang diinduksi Alloxan. Rata-rata penurunan kadar gula darah P3 (42.80 mg/dL) tanpa perbedaan signifikan dibandingkan glimepirid $0.1 \mathrm{mg} / \mathrm{kgBB} /$ hari $(21.60 \mathrm{mg} / \mathrm{dL})$.

\section{UCAPAN TERIMA KASIH}

Terima kasih kepada Laboratorium Farmakologi Fakultas Kedokteran Universitas Airlangga di Surabaya yang telah memfasilitasi pelaksanaan penelitian ini. Terima kasih kepada Alm. Sunarni Zakaria, dr., M.Si, selaku pembimbing dalam pelaksanaan penelitian ini.

\section{DAFTAR PUSTAKA}

Katzung, B., Susan, G., Masters, B., Anthony J.T. 2012. Basic \& clinical pharmacology. New York: McGraw-Hill Medical, p363372.

Lenzen, S. 2008. The mechanisms of alloxan and streptozotocin induced diabetes. Diabetol., 51(2), 216-226.
Leonita, E., Muliani, A. 2015. Penggunaan Obat Tradisional oleh Penderita Diabetes Mellitus dan Faktor-faktor yang Berhubungan di Wilayah Kerja Puskesmas Rejosari Pekanbaru Tahun 2015. J. Kes. Komunitas, 3(1), 47-52.

Mwafy, S., Yassin, N., Maged, M. 2011. Antidiabetic Activity Evaluation of Glimepiride and Nerium oleander Extract on Insulin, Glucose Levels and Some Liver Enzymes Activities in Experimental Diabetic Rat Model. Pak. J. Biol. Sci., 14, 984-990.

Rudijanto, A., Yuwono, A., Shahab, A., Manaf, A., Pramono, B., Lindarto, D., Purnamasari, D., Sanusi, H., Zufry, H., Novida, H., Suastika, K., Sucipto, K.W., Sasiarni, L., Dwipayana, M.P., Saraswati, M.R., Soetedjo, N.N., Soewondo, P., Soelistijo, S. A., Sugiarto, Langi, Y.A. 2015. Konsensus Pengelolaan dan Pencegahan Diabetes Melitus Tipe 2 di Indonesia 2015. PB PERKENI, p6-9.

Saputra, N., Suartha, I., Dharmayudha, A. 2018, Agen Diabetagonik Streptozotocin untuk Membuat Tikus Putih Jantan Diabetes Mellitus. Buletin Vet. Udayana, 116.

Sitorus, E., Hastuti, E., Setiari, N. 2011. Induksi Kalus Binahong (Basella rubra L.) Secara In Vitro Pada Media Murashige \& Skoog Dengan Konsentrasi Sukrosa Yang Berbeda, BIOMA, 13(1).

Suryani, N., Septiana, H. 2016. Diet dan Olahraga sebagai Upaya Pengendalian Kadar Gula Darah pada Pasien Diabetes Melitus Tipe 2 di Poliklinik Penyakit Dalam RSUD Ulin Banjarmasin Tahun 2015. J. Kes. Indones., 6(2). 